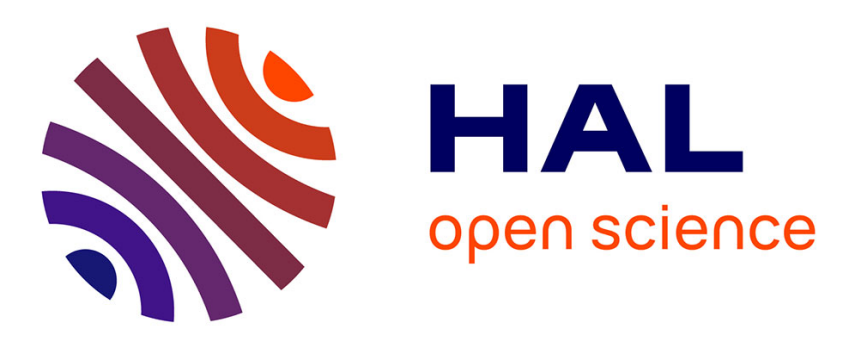

\title{
Why Is Tetradentate Coordination Essential for Potential Copper Homeostasis Regulators in Alzheimer's Disease?
}

Youzhi Li, Michel Nguyen, Morgane Baudoin, Laure Vendier, Yan Liu, Anne Robert, B. Meunier

\section{To cite this version:}

Youzhi Li, Michel Nguyen, Morgane Baudoin, Laure Vendier, Yan Liu, et al.. Why Is Tetradentate Coordination Essential for Potential Copper Homeostasis Regulators in Alzheimer's Disease?. European Journal of Inorganic Chemistry, 2019, 2019 (44), pp.4712-4718. 10.1002/ejic.201900951 . hal-02399299

\section{HAL Id: hal-02399299 \\ https://hal.science/hal-02399299}

Submitted on 10 Nov 2020

HAL is a multi-disciplinary open access archive for the deposit and dissemination of scientific research documents, whether they are published or not. The documents may come from teaching and research institutions in France or abroad, or from public or private research centers.
L'archive ouverte pluridisciplinaire HAL, est destinée au dépôt et à la diffusion de documents scientifiques de niveau recherche, publiés ou non, émanant des établissements d'enseignement et de recherche français ou étrangers, des laboratoires publics ou privés. 


\title{
Why tetradentate coordination is essential for potential copper homeostasis regulators in Alzheimer's disease?
}

\author{
Youzhi Li, ${ }^{[a, b]}$ Michel Nguyen, ${ }^{[a]}$ Morgane Baudoin, ${ }^{[a]}$ Laure Vendier, ${ }^{[a]}$ Yan Liu, ${ }^{[b]^{*}}$ Anne Robert,,${ }^{\left[a{ }^{*}\right.}$ \\ Bernard Meunier ${ }^{[a, b]^{*}}$
}

Dedicated to Jean-Marie Lehn for his 80th birthday

\begin{abstract}
Research of effective drugs against Alzheimer's disease $(A D)$ is currently one of the most challenging topics in medicinal chemistry. Despite the documented detrimental effect of the disruption of copper ion homeostasis in $A D$, this potential pharmacological target has been weakly explored. The design of chelators as drug candidates for copper regulation in $A D$ brain should obey to critical coordination chemistry requirements, in addition to requested biological parameters (membrane crossing, activity, ...). Among the various possibilities offered by the diversity of metal ligands, we found that N4-tetradentate 8-aminoquinoline ligands able to generate stricly square planar $\mathrm{Cu}(\mathrm{II})$ complexes, are the most suitable for the transfer of copper from metal-amyloids to metal-carrier proteins, and are able to inhibit the catalytic reduction of dioxygen produced by copper-loaded amyloids exposed to a biological reductant. In vivo, such tetradentate ligands are able to inhibit the loss of episodic memory in non-transgenic amyloidimpaired mice.
\end{abstract}

\section{Introduction}

Among all physiological modifications and diseases due to aging, Alzheimer's disease (AD) is the most feared for many reasons. This neurodegenerative disease has a very high prevalence for people over 75 year old, ${ }^{[1 \mathrm{a}]}$ and is currently one of the most common diseases for which there is no efficient therapeutic agent available. More than 44 million people are suffering dementia in the World, $50-70 \%$ of which are AD patients. ${ }^{[1 b]}$ Only five drugs (tacrine, donepezil, rivastigmine, galantamine and memantine) have been approved up to now and many national health insurances decided to stop their reimbursement considering the poor efficiency of these molecules and the high level of side-effects. ${ }^{[2]}$

Efforts from academic or industrial laboratories have been unsuccessful up to now. Despite a considerable number of clinical trials and a rather limited diversity of mechanistic

[a] Dr. M. Nguyen, Dr A. Robert, Pr. B. Meunier

Laboratoire de Chimie de Coordination du CNRS (LCC-CNRS), 205

route de Narbonne, BP 44099, 31077 Toulouse cedex 4, France and

Université de Toulouse, 31077 Toulouse Cedex 4, France.

E-mail: anne.robert@lcc-toulouse.fr and bmeunier@lcc-toulouse.fr https://www.lcc-toulouse.fr/article805.html

[b] Mr Y. Li, Pr Y. Liu, Pr. B. Meunier, School of Chemical Engineering and Light Industry, Guangdong University of Technology (GDUT), Higher Education Mega Center, 100 Waihuan Xi road, Panyu District, Guangzhou, 510006, P. R. China.

E-mail: yanliu@gdut.edu.cn

Supporting information for this article is given via a link at the end of the document. approaches, all attempts failed in the period 2002-2012, making the research on anti-AD drugs the most difficult challenge in drug discovery. ${ }^{[3]}$ At the beginning of 2018, more than 110 drugcandidates were investigated in clinical trials. ${ }^{[4]}$ Among the 64 drugs in phase II, $30 \%$ of them targeted amyloids $(A \beta), 14 \%$ were acting on tau and $33 \%$ were potential symptomatic cognitive enhancers.

Many questions are currently without answers. What kind of lessons have been obtained from all these failures with anti-AD drugs? Why hundreds of clinical trials with antibodies failed? Why the possible crossing of the blood-brain barrier by antibodies has been over-estimated? Why we forgot that nearly all drugs that have a pharmacological activity and/or a toxic effect on the central nervous system in the brain are small chemical molecules having molecular weights below 500-700 Da? Why the scope of drug-targets has not been enlarged enough? Why the sporadic AD (the major non-genetic form of $A D$ ) has been treated as a di- or tri-genic disease with nearly all rodent models based on transgenic mouse models? The necessity of the animal model diversification has been pointed out in 2010. [5]

After so many failures in drug development, it is urgent to enlarge the scope of approaches, targets, and animal models, even those considered as non-conventional by committees of different funding agencies that have a tendency to support research projects closely related to the own-field of the committee members. At this game, the winners are often the representative of the largest and most organized scientific communities. It is important to facilitate the access of funding to research groups looking outside of the enlightened zones of the main "street lamps" of the research communities.

Many biochemical processes, and consequently putative targets, are involved in $A D$ pathology. Among them, the detrimental effect of the disruption of metal ion homeostasis in $A D$ brain has been well documented. ${ }^{[6]}$ Despite evidences of the deleterious oxidative stress potentially catalyzed by redox active transition metals, this approach is roughly below $1-2 \%$ of all attempts in $A D$ drug design. ${ }^{[7]}$

In this review article, we would like to draw attention of drugdesigners interested by metal chelators for $A D$ treatment, on the following fact: to have a chance to produce suitable drugcandidates able to target the disruption of metal homeostasis, it is essential to take in consideration basic coordination chemistry. As a matter of fact, we suggest a correlation between (i) the coordination sphere offered by copper chelators based on a 8aminoquinoline, designed as regulators of copper homeostasis for $A D$ therapy, ${ }^{[8]}$ (ii) the X-ray structures of the resulting $\mathrm{Cu}$ (II) complexes, and the selectivity of these ligands for $\mathrm{Cu}$ with respect to several other metals, (iii) the efficiency of these chelators to extract $\mathrm{Cu}(\mathrm{II})$ from amyloids and inhibit the 
production of reactive oxygen species (ROS) induced by $\mathrm{Cu}-\mathrm{A} \beta$ complexes, and (iv) the inhibition of the loss of cognitive impairment of $A D$ mice.

\section{Tetradentate chelators as regulators of copper homeostasis for AD treatment: bis(8- aminoquinolines) and mono-8- aminoquinolines (TDMQ series)}

$A \beta$ protein has been, and is still a popular target for the design of anti-AD drugs. But the capacity of amyloids to accumulate redox active metal ions is making metal-amyloids as pertinent drug targets. The link between $A D$ and the redox metal dysregulation in the brain is offering alternative therapeutic solutions. ${ }^{[6 a, c]}$ This approach is strongly supported by post-mortem analyses of amyloid plaques, which indicate an excessive accumulation of copper, iron, and zinc ions by factors of 5.7, 2.8, and 3.1 times, respectively, the levels observed in normal brains. ${ }^{[9]}$ Copper-amyloid complexes, in the presence of endogenous reductants, are able to catalyze the reduction of dioxygen to generate reduced/reactive oxygen species (ROS) involved in massive neuron death. ${ }^{[10]}$ Therefore, the use of specific metal chelators can be considered as a promising way to reduce redox stress, by regenerating normal trafficking of metal ions. ${ }^{[11]}$ It should be noted that early attempts to develop chelators have been made with non-specific chelators, such as, the "classic" non-selective chelator EDTA, or hydroxyquinoline derivatives like clioquinol and PBT2. The inefficiency of these ligands is partly due to their lack of selectivity for copper, and/or their incapacity to inhibit the production of ROS induced by $\mathrm{Cu}-\mathrm{A} \beta$. Taking these failures in consideration, ${ }^{[12]}$ and based on our initial work on bis(8-aminoquinoline) derivatives PA1637 and AD3, ${ }^{[8,13]}$ we designed a new series of chelators, named TDMQ (for tetradendate-monoquinolines) (Scheme 1), able to offer a tunable coordination sphere for $\mathrm{Cu}(\mathrm{II})$, and to meet the requirements for a drug-candidate susceptible to specifically regulate copper homeostasis in the brain of $A D$ patients. ${ }^{[8 a]}$

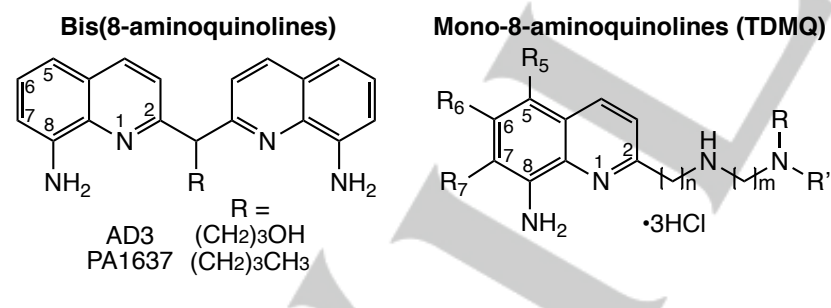

Scheme 1. General structures of bis(8-aminoquinolines) and TDMQ chelators.

2.1. Correlation between the affinity of TDMQ ligands for $\mathrm{Cu}(\mathrm{II})$ and X-ray structure of $\mathrm{Cu}$-TDMQ complexes

TDMQ ligands were designed to provide chelation of $\mathrm{Cu}(\mathrm{II})$ using the two aromatic nitrogen atoms of the quinoline nucleus, and two nitrogen atoms of the modular side chain. The determination of many 3D-structures of these ligands with different metals has been very helpful to understand the key parameters of their chelation properties. The X-ray diffraction structures of single crystals of the Cu(II) complexes of TDMQ5, TDMQ19, TDMQ20, TDMQ22, and TDMQ37 are summarized in Scheme $2 .{ }^{[14]}$ Both TDMQ20 and TDMQ22 ligands, with a side chain $n=m=2$ (Scheme 1 ) offered a tetradentate square planar coordination sphere around the copper(II) ion, generating N4 copper complexes with five, six, and five-membered rings, respectively, in the $\mathrm{N} 4$ equatorial plane. The $\alpha$ and $\beta$ angles were in the range $92.8-97.6^{\circ}$, while $\gamma$ and $\delta$ values were slightly lower at $83.6-85.7^{\circ}$ (Table 1 ), due to a small elongation along the $\gamma-\delta$ axis. One or two additional apical ligands (not drawn) were water or chloride anion. The presence of a single chloride as apical ligand [TDMQ20(A)] produced a slight doming of the tetradendate structure, with the $\mathrm{Cu}(\mathrm{II})$ located at $0.17 \AA$ above the $\mathrm{N} 4$ mean plane. With one $\mathrm{H}_{2} \mathrm{O}$ [TDMQ20(B)] or two chlorides (TDMQ22) in apical positions, the N4 square plane is nearly perfect, with dihedral angles $\mathrm{N} 1-\mathrm{Cu}-\mathrm{N}_{\text {aniline }} / \mathrm{N} 1-\mathrm{Cu}-\mathrm{N}_{\text {proximal }}$ and $\mathrm{N} 1-\mathrm{Cu}-\mathrm{Naniline} / \mathrm{N}$ proximal-Cu$-\mathrm{N}$ distal below $2.5^{\circ}$, and the distance between $\mathrm{Cu}$ and the N4-mean plane below $0.03 \AA$. The complex Cu-TDMQ37 exhibits also this N4 geometry, but this latter complex is slightly distorted, due to a shorter $\mathrm{C}-\mathrm{N}_{\text {distal }}$ distance, induced by the aromatic character of the distal pyridine $(1.393 \AA$, compared to $1.479-1.480 \AA$ in $\mathrm{Cu}-\mathrm{TDMQ} 20$ and $\mathrm{Cu}-\mathrm{TDMQ22}$ ). As expected, these ligands, giving rise to N4-tetradentate square planar complexes, exhibited a very high affinity for $\mathrm{Cu}(\mathrm{II})$, with $\log K_{\text {aff }}$ values around 16 at $\mathrm{pH} 7.4 .^{[8 \mathrm{a}]}$ Noteworthy, the AD3 ligand, based on a bis-8-aminoquinoline skeleton, produces also such N4 Cu(II) complex, and had also a high affinity constant for $\mathrm{Cu}(\mathrm{II})\left(\log K_{\text {aff }}=16.5\right.$ at $\mathrm{pH} 7.4$, Table 2$){ }^{[8 \mathrm{cc}]}$

Conversely, the ligands TDMQ5 and TDMQ19, with only one methylene group between the $\mathrm{C} 2$ position and the proximal nitrogen of the side chain $(n=1$, Scheme 1$)$, give rise to two fused 5-membered rings in the equatorial plane of the $\mathrm{Cu}$ (II) complexes [Cu(II)-complexes N3, Scheme 2]. The constraint due to this structure prevented coordination of the distal amine to the central copper ion, whatever was the $\mathrm{N}_{\text {proximal }}-\mathrm{N}_{\text {distal }}$ distance. The $\mathrm{Cu}$ coordination in the equatorial plane was then completed by a chloride anion, generating a $\mathrm{N} 3 \mathrm{Cl}$ coordination. As a consequence, these ligands exhibited a much lower affinity for $\mathrm{Cu}(\mathrm{II})$ with $\log K_{\text {aff }}$ values $=10$ at $\mathrm{pH} 7.4 .^{\left[{ }^{8 \mathrm{a}}\right]}$

When the distal nitrogen atom of the chelator is included in a saturated 6-membered cycle (TDMQ35 and TDMQ36, Scheme 2 ), the $\log K_{\text {aff }}[\mathrm{Cu}-\mathrm{TDMQ35}$ or TDMQ36] values at $\mathrm{pH} 7.4$ were 13.7 and 13.1, respectively, three orders of magnitude higher than those observed for $\mathrm{N} 3 \mathrm{Cu}(\mathrm{II})$-complexes, but significantly lower than the values obtained with $\mathrm{N} 4 \mathrm{Cu}(\mathrm{II})$ - complexes. In the absence of single crystals of Cu-TDMQ35 or TDMQ36 suitable for X-ray crystallography, we propose that the steric hindrance generated by the distal morpholine (TDMQ36) or piperidine (TDMQ35) resulted in an equilibrium between N3 and N4 chelation of copper in solution, responsible for a lower metal affinity. 
(a)<smiles>CN(C)CNCc1ccc2c(Cl)cc(Cl)c(N)c2n1</smiles>

(b)

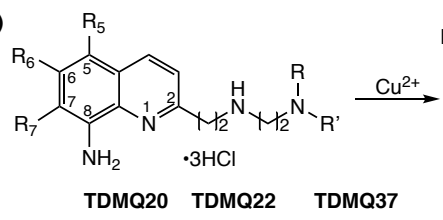
$\mathrm{R}_{5}=\mathrm{R}_{7}=\mathrm{Cl}$

$\mathrm{R}_{6}=\mathrm{H}$ $\mathrm{R}, \mathrm{R}^{\prime}=\mathrm{CH}_{3}$ $\begin{array}{cc}\mathrm{H} & \mathrm{Cl} \\ \mathrm{CF}_{3} & \mathrm{H}\end{array}$ $\mathrm{CH}_{3} \quad \mathrm{R}, \mathrm{R}^{\prime}=o$-pyridine

(c)<smiles>[X]CCCN(CCO)CNCc1ccc2c(Cl)cc(Cl)c(N)c2n1</smiles>

Scheme 2. Structures of TDMQ5, 19, 20, 22, 35-37, and of the corresponding $\mathrm{Cu}(\mathrm{II})$ complexes, associated with the affinity of these ligands for $\mathrm{Cu}(\mathrm{II})$ at $\mathrm{pH}$ 7.4. For clarity, apical ligand(s) on the $\mathrm{Cu}$ centre are not drawn, there is one chloride in Cu-TDMQ19 and $\mathrm{Cu}-\mathrm{TDMQ}_{2}(\mathrm{~A})$, a water molecule in $\mathrm{Cu}-\mathrm{TDMQ5}$,

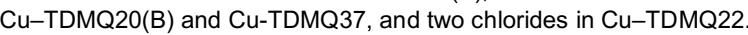

\begin{tabular}{|c|c|c|c|c|c|c|}
\hline Chelator & TDMQ5 & TDMQ19 & TDMQ20(A) & TDMQ20(B) & TDMQ22 & TDMQ37 \\
\hline \multicolumn{7}{|l|}{ Angles } \\
\hline$\alpha$ & $79.37^{\circ}$ & $80.39^{\circ}$ & $92.81^{\circ}$ & $93.64^{\circ}$ & $93.45^{\circ}$ & $92.43^{\circ}$ \\
\hline$\beta$ & - & - & $96.79^{\circ}$ & $96.88^{\circ}$ & $97.55^{\circ}$ & $100.60^{\circ}$ \\
\hline$\gamma$ & $82.91^{\circ}$ & $82.13^{\circ}$ & $83.59^{\circ}$ & $83.72^{\circ}$ & $84.23^{\circ}$ & $82.98^{\circ}$ \\
\hline$\delta$ & - & - & $85.42^{\circ}$ & $85.72^{\circ}$ & $84.81^{\circ}$ & $81.57^{\circ}$ \\
\hline \multicolumn{7}{|l|}{ Diedral angles } \\
\hline $\begin{array}{l}\mathrm{N} 1-\mathrm{Cu}-\mathrm{N}_{\text {aniline }} / \\
\mathrm{N}_{1}-\mathrm{Cu}-\mathrm{N}_{\text {prox }}\end{array}$ & $8.32^{\circ}$ & $9.59^{\circ}$ & $5.57^{\circ}$ & $1.45^{\circ}$ & $1.75^{\circ}$ & $16.35^{\circ}$ \\
\hline $\begin{array}{c}\mathrm{N} 1-\mathrm{Cu}-\mathrm{N}_{\text {aniline }} / \\
\mathrm{N}_{\text {proximal }}-\mathrm{Cu}-\mathrm{N}_{\text {distal }}\end{array}$ & - & - & $14.24^{\circ}$ & $1.05^{\circ}$ & $2.30^{\circ}$ & $14.47^{\circ}$ \\
\hline $\begin{array}{l}\mathrm{N} 1-\mathrm{Cu}-\mathrm{N}_{\text {proximal }} \\
\mathrm{N}_{\text {proximal }}-\mathrm{Cu}-\mathrm{N}_{\text {distal }}\end{array}$ & - & - & $13.40^{\circ}$ & $1.55^{\circ}$ & $1.42^{\circ}$ & $7.60^{\circ}$ \\
\hline $\begin{array}{c}\text { Distance } \\
\text { Cu-N4 plane }\end{array}$ & - & - & $0.172 \AA$ & $0.027 \AA$ & $0.003 \AA$ & $0.195 \AA$ \\
\hline
\end{tabular}

Table 1. X-Ray crystallographic data for the Cu(II) complexes of TDMQ5, TDMQ19, TDMQ20, TDMQ22, TDMQ37.

Selectivity of TDMQ for Cu(II) with respect to Zn(II). Chelation of $\mathrm{Zn}(\mathrm{II})$ by TDMQ ligands was investigated. In fact, $\mathrm{Zn}^{2+}$ is essential for life and is the second most abundant d-block metal after iron in the human body, especially in the brain where it is associated with memory and learning. ${ }^{[16]}$ In the X-ray crystallographic structures of the zinc complexes of TDMQ5, TDMQ19, TDMQ20, and TDMQ37, Zn(II) was chelated in a
$\mathrm{N} 2 \mathrm{Cl} 2$ tetrahedral environment provided by the two nitrogen atoms of the side chain, and two chloride anions. The aminoquinoline nucleus did not take part in the zinc coordination. These structures are consistent with the low affinity constants of TDMQ ligands for $\mathrm{Zn}(\mathrm{II})\left(\log K_{\mathrm{app}} \leq 5.2\right.$ at $\mathrm{pH} 7.4$, Table $2{ }^{[8 a]}$ Consequently, the selectivity of TDMQ ligands for $\mathrm{Cu}$ (II) with respect to $\mathrm{Zn}$ (II) was very high, the affinity for $\mathrm{Cu}$ (II) being 10-12 orders of magnitude higher than that for $\mathrm{Zn}$ (II). The $\mathrm{Cu} / \mathrm{Zn}$ selectivity of the former drug-candidates 8hydroxyquinoline derivatives clioquinol (CQ) and PBT2 was far lower, only 3 orders of magnitude. The relatively high affinity of these two later ligands for zinc facilitates their interaction with zinc-proteins or unbound zinc in vivo, a mechanism involved in the neurotoxicity of $\mathrm{CQ}^{\cdot{ }^{[17]}}$ Bis-8-aminoquinolines and TDMQ ligands, designed to fit the N4 square planar chelation preferred for $\mathrm{Cu}(\mathrm{II})$, are not well suited for the tetrahedral coordination sphere of $\mathrm{Zn}$ (II). In addition, CQ and PBT2 have a preference for a two ligands per metal stoichiometry. Such a 2 to 1 ligand/metal ratio induces the high versatility of these ligands for the coordination of different metal ions, such as copper or zinc.

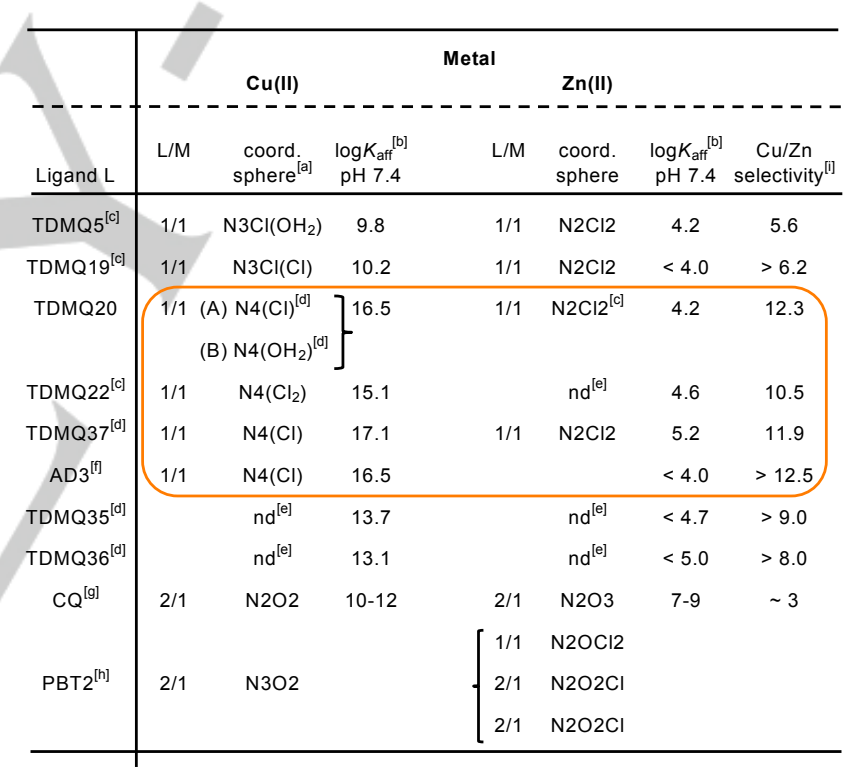

${ }^{a}$ The main indicated ligands are those of the square plane; in the parentheses, apical ligands are noted. Where only three nitrogen ligands are involved in the $\mathrm{Cu}(\mathrm{II})$ coordination sphere, it is the 2 aminoquinoline nitrogens and $\left.\mathrm{N}_{\text {proximal. }}{ }^{\mathrm{b}} \log \mathrm{Kaff}_{\mathrm{aff}} \mathrm{Cu}-\mathrm{L}\right]$ at $\mathrm{pH}$ 7.4. ${ }^{\mathrm{c}}$ Reference $8 \mathrm{a}^{\mathrm{d}}$ This work. ${ }^{\mathrm{e}}$ Not determined. ${ }^{\mathrm{f}}$ Reference 13a. ${ }^{9}$ Reference 15. Reference 12. ${ }^{\prime} \log K_{\text {aff }}[\mathrm{Cu}-\mathrm{L}]-\log K_{\text {afff }}[\mathrm{Zn}-\mathrm{L}]$ at $\mathrm{pH} 7.4$.

Table 2. Correlation between the affinities of TDMQ ligands for $\mathrm{Cu}(\mathrm{II})$ and $\mathrm{Zn}$ (II) and the coordination spheres of the corresponding complexes determined by X-Ray crystallography; data on AD3, CQ, and PBT2 are given for comparison.

The design of TDMQ ligands able to generate N4 Cu(II)complexes provides also essential features for potential agents in $A D$ therapy. For example, these ligands have been shown able to efficiently extract $\mathrm{Cu}^{2+}$ from $\mathrm{Cu}(\mathrm{II})-\mathrm{A} \beta$ complexes, ${ }^{[13 b, 8 \mathrm{a}]}$ even in the presence of a millimolar concentration of zinc. ${ }^{[8 b]}$ 
However, despite their high affinities for $\mathrm{Cu}(\mathrm{II})$, it is remarkable that these metal chelators do not disturb the biological activity of essential copper enzymes involved in brain biochemistry (tyrosinase) or regulation of reactive oxygen species (superoxide dismutase). ${ }^{[18]}$ TDMQ ligands are also unable to remove the cobalt ion from vitamin B12. ${ }^{[18]}$

What is the behavior of TDMQ ligands with iron, calcium or magnesium ions? Besides zinc, drug-candidates for regulation of copper homeostasis in $A D$ brain must not interfere with other biological metal such as iron, or biologically important alkaline earth cations, like $\mathrm{Ca}^{2+}$ and $\mathrm{Mg}^{2+}$, whose concentration in cerebrospinal fluid is close to $1 \mathrm{mM} \cdot{ }^{[19]}$ To evaluate the putative affinity of TDMQ chelators for $\mathrm{Fe}(\mathrm{III}), \mathrm{Ca}(\mathrm{II})$ and $\mathrm{Mg}(\mathrm{II})$, we carried out the titration of TDMQ5, TDMQ19, TDMQ20, TDMQ35-37 by the corresponding salts at $\mathrm{pH} 7.4$. In all cases, the ligand was not metalated upon addition of $\mathrm{FeCl}_{3}$ (up to 10 mole equivalents with respect to the ligand) or $\mathrm{MgCl}_{2}$ or $\mathrm{CaCl}_{2}$ (up to 100 mole equivalents with respect to the ligand) (For experimental details, see Supporting information). These results indicate that TDMQ chelators are unlikely to interfere in vivo with these biologically relevant metal ions. This is not the case with 8-hydroxyquinoline which forms stable 2/1 complex with $\mathrm{Mg}^{2+}$ and $\mathrm{Ca}^{2+},{ }^{[20]}$ and should be avoided.

\subsection{Correlation between the ability of TDMQ ligands to inhibit ROS production and X-ray structures of $\mathrm{Cu}$-TDMQ complexes}

We measured the ascorbate oxidation catalyzed by $\mathrm{Cu}-\mathrm{A} \beta_{1-16}$ in the presence of TDMQ chelators, as an indirect evaluation of the ability of TDMQ ligands to inhibit the reduction of dioxygen and the subsequent production of ROS in the presence of biological reductants. While oxidation of ascorbate was $>98 \%$ in the presence of $\mathrm{CuCl}_{2}$ (as a positive control) and $57 \%$ in the presence of $\mathrm{Cu}-\mathrm{A} \beta_{1-16}$ after $10 \mathrm{~min}$, it was below $5 \%$ in the presence of 1 mole equiv of the all the N4 chelators AD3, TDMQ20, TDMQ22 or TDMQ37, in the same range than ascorbate autoxidation (Scheme 3, left). ${ }^{[13 b, 8 a}$, for TDMQ37, see also the SI section of the present review] In addition, such ligands are able to immediately and fully inhibit the ongoing oxidation of ascorbate, even in the presence of 10 mole equiv of $\mathrm{Zn}^{2+}$ (Scheme 3, right). ${ }^{[\mathrm{b}]}$ These results strongly suggest that such ligands should be able to inhibit an ongoing redox stress in brain, a zinc rich medium. On the opposite, the N3 chelators, TDMQ5 and TDMQ19, failed to efficiently inhibit the ascorbate oxidation. ${ }^{[8]}$ Under the same conditions, 2 mole equiv of PBT2 also failed to inhibit ascorbate oxidation. ${ }^{[13 b]}$ TDMQ35 and TDMQ36 only partly inhibited ascorbate oxidation ( $20 \%$ and $40 \%$ of inhibition with TDMQ35 and TDMQ36, respectively), a result consistent with the significantly lower affinity of these TDMQ ligands for $\mathrm{Cu}$ (II) (see Supporting Information)

In reaction mixtures containing $\mathrm{Cu}$ "I-A $\beta_{1-16}$ associated with ascorbate, the inhibition of $\mathrm{H}_{2} \mathrm{O}_{2}$ production in the presence of N4 chelators was measured using the fluorescence of a peroxidase substrate. In the presence of AD3, TDMQ20, TDMQ22, or TDMQ37, the production of $\mathrm{H}_{2} \mathrm{O}_{2}$ was only $7-9 \%$ compared to that produced by $\mathrm{Cu}^{\prime \prime}-\mathrm{A} \beta_{1-16}$ in the absence of N4 chelator. The N3 chelators TDMQ5, TDMQ19, TDMQ35 and TDMQ36 resulted in only partial inhibition of $\mathrm{H}_{2} \mathrm{O}_{2}$ production. ${ }^{8 a}$, SI of the present reviewt]

In fact, N4-tetradentate chelators designed to exclusively chelate $\mathrm{Cu}(\mathrm{II})$ in a metal/ligand $=1 / 1$ square planar environment are able to readily and irreversibly extract $\mathrm{Cu}$ from $\mathrm{Cu}^{11}-\mathrm{A} \beta^{[8,13]}$ The resulting Cul-TDMQ complexes are redox inactive, due to the inability of these ligands to accommodate the tetrahedral structure of putative $\mathrm{Cu}(\mathrm{I})$ complexes. This structural fact is the main reason why AD3 and N4-TDMQ ligands efficiently inhibit the production of ROS induced by $C u^{\prime \prime}-A \beta$. Conversely, the bidentate $C Q$ and tridentate PBT2 offer a much more versatile coordination sphere giving rise to copper complexes whose metal/ligand stoichiometry can be $1 / 2$. In the presence of $\mathrm{Cu}^{\prime \prime}-$ $A \beta$, these ligands form ternary complexes, $A \beta-C u-C Q$ or $A \beta-$ $\mathrm{Cu}-\mathrm{PBT} 2$, able to accommodate both $\mathrm{Cu}(\mathrm{I})$ and $\mathrm{Cu}(\mathrm{II})$ oxidation states. Consequently these ternary complexes containing amyloids can retain a significant redox activity. ${ }^{[13 b]}$
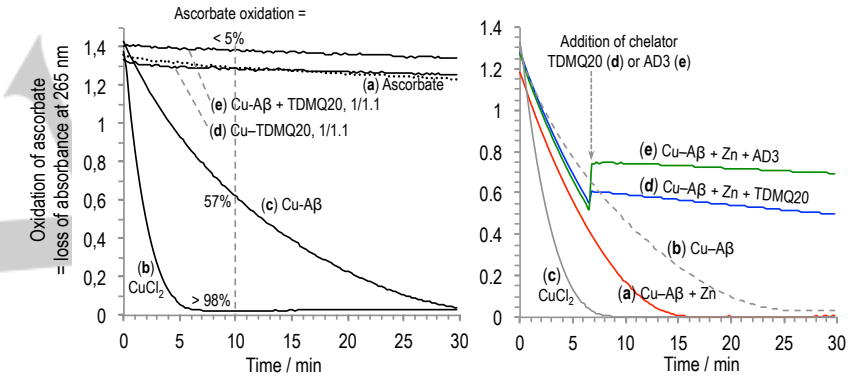

Scheme 3. Left. UV-visible $(265 \mathrm{~nm})$ kinetic spectra of ascorbate oxidation under air in the presence of (a) no additive (dotted line), (b) $\mathrm{CuCl}_{2}$, (c) $\mathrm{Cu}^{\prime \prime}-$ $A \beta_{1-16}, 1 / 1$, (d) Cull-TDMQ20, 1/1.1, (e) Cu"l-A $\beta_{1-16}, 1 / 1$, + TDMQ20 (1.1 mole equiv). Right. UV-visible (265 nm) kinetic spectra of ascorbate oxidation under air, in the presence of $\mathrm{CuCl}_{2} / \mathrm{A}_{1-16} / \mathrm{ZnCl}_{2}=1 / 1 / 100$, then addition of $\mathrm{L}(1 \mathrm{~mol}$ equiv) at $6.6 \mathrm{~min}$ (arrow): $\mathrm{L}=$ no ligand (trace a), $L=$ TDMQ20 (trace d), $L=$ AD3 (trace e). The ascorbate oxidation in the presence of $\mathrm{CuCl}_{2} / \mathrm{A}_{1-16}$, (trace b) $\mathrm{CuCl}_{2}$ (trace c) are given for comparison. The increase of absorbance upon addition of TDMQ20 (d) or AD3 (e) at $6.6 \mathrm{~min}$, is due to the own absorbance of Cu"-TDMQ20, or Cu"-AD3 at $265 \mathrm{~nm}$.

Finally the release of copper from Cu"-AD3 and Cu"-TDMQ complexes is efficiently achieved in the presence of glutathione, which is a physiological provider of copper to proteins. In fact, GSH acts both as a reducing agent for copper ion, and as a competitive ligand for the generated $\mathrm{Cu}(\mathrm{I})$, giving rise to the $\mathrm{Cu}(\mathrm{I})$-glutathione complex. ${ }^{[13 \mathrm{~b}]}$ After addition of 80-200 mole equiv of GSH with respect to $\mathrm{Cu}$-chelator complexes, corresponding to biological $\mathrm{mM}$ concentrations of $\mathrm{GSH}$, the release of the chelators allow these ligand to act as catalysts for the extraction of $\mathrm{Cu}$ (II) from the amyloid peptide (Scheme 4).

As a summary, the ability of chelators to generate $\mathrm{Cu}(\mathrm{II})$ complexes with a metal/ligand stoichiometry $=1 / 1$, and a N4 square planar coordination of copper should be considered a prerequisite for effective regulation of copper homeostasis and oxidative stress inhibition in the context of $A D$ therapy. 


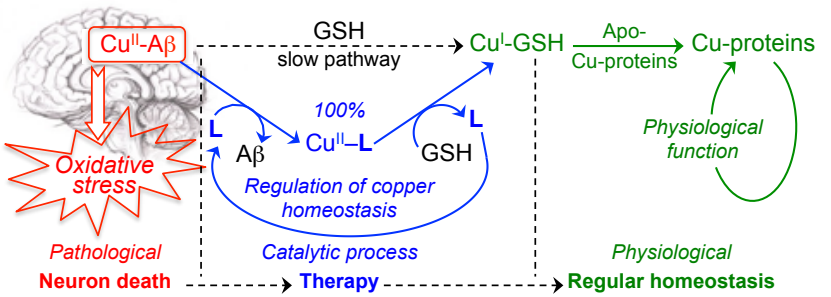

Scheme 4. Transfer of copper ions from $\mathrm{Cu}-\mathrm{A} \beta$ to $\mathrm{Cu}$-proteins, using the N4tetradentate chelators, AD3, TDMQ20, 22, and 37.

\subsection{Druggability of TDMQ chelators}

TDMQ20, TDMQ22 and TDMQ37 do not inhibit essential copper enzymes.

Since TDMQ20, TDMQ22 and TDMQ37 chelators have a high affinity for $\mathrm{Cu}(\mathrm{II})$ and are expected to regulate copper homeostasis in the brain, the question whether these chelators might be able to demetalate, and therefore inhibit, essential copper proteins is obviously important, and should be answered before clinical development could be considered. We therefore examined the possible interaction of these chelators with physiological copper proteins, and related metal biomolecules. Despite the fact that they are able to chelate cobalt(II) [but not $\mathrm{Co}(\mathrm{III})]$, they have been found unable to demetalate vitamin B12, even in the presence of millimolar concentrations of glutathione. On the other hand, upon incubation for $1 \mathrm{~h}$ at $37{ }^{\circ} \mathrm{C}$, the $\mathrm{IC}_{50}$ values of these TDMQ chelators for mushroom tyrosinase were higher or equal to $2 \mathrm{mM}$ for TDMQ20 and TDMQ22, ${ }^{[18]}$ and 100 $\mu \mathrm{M}$ for TDMQ37 (Scheme S7). The IC 50 values of TDMQ20 and TDMQ22 for bovine $\mathrm{Cu}, \mathrm{Zn}-\mathrm{SOD}$ were $1.5 \mathrm{mM}$ and higher than 1 $\mathrm{mM}$ for TDMQ20 and TDMQ22, respectively. TDMQ37 at 0.65 $\mathrm{mM}$ did not inhibited bovine $\mathrm{Cu}, \mathrm{Zn}-\mathrm{SOD}$ (Scheme S8). These concentrations are much higher than the chelator concentration that is expected to occur in vivo. In fact, the plasma and brain concentrations of clioquinol and PBT2 reported in wild type or transgenic mice were lower by three orders of magnitude (in the $0.3-4 \mu \mathrm{M}$ range, $2 \mathrm{~h}$ after a $30 \mathrm{mg} / \mathrm{kg}$ single oral treatment). ${ }^{[21]}$ So, the TDMQ chelators should probably be unable to interfere in vivo with the biological activity of these essential metalloenzymes involved in brain biochemistry or regulation of oxygen metabolism.

Preliminary metabolic studies indicate that the TDMQ chelators significantly inhibits CYP 2D6, but not CYP 3 A $(<20 \%)$ and $2 \mathrm{C9}(<5 \%)$. These chelators are Ames negative and not cytotoxic below $0.1 \mathrm{mM}$.

The measured $\mathrm{pK}$ a values indicate that, at physiological $\mathrm{pH}$, TDMQ20, TDMQ22, and TDMQ37 should exist as a mixture of species, due to mono- and diprotonation of the side chain (Supporting Information), like most CNS drugs which have basic properties. ${ }^{[22]}$ At physiological $\mathrm{pH}$, the corresponding $\mathrm{Cu}(\mathrm{II})$ complexes are expected to be dicationic species, due to the chelation of $\mathrm{Cu}$ (II) by a neutral TDMQ ligand. However, in the chloride rich biological medium (chloride concentration is 160$190 \mathrm{mM}$ in blood serum and in cerebrospinal fluid), the net positive charge of the Cu-TDMQ complexes is expected to be partly of fully neutralized by apical coordination of chloride anions, as suggested by the solid state structures (Supporting Information). The calculated $\log P$ values for TDMQ20, TDMQ22, and TDMQ37 are in the range 2.3-3.3, and topological polar surface area values (tPSA) are below $63 \AA^{2},{ }^{[23]}$ properties consistent with passive transport of these drugs across the BBB. ${ }^{[22]}$ These three chelators are therefore considered as lead drugs to regulate copper homeostasis in the brain of $A D$ patients.

\section{Correlation between the ability of PA1637 to inhibit cognitive impairment in mice and the $\mathrm{X}$-ray structure of Cu-AD3 complex}

To evaluate the ability of copper chelators to reduce the loss of memory in vivo, after unreliable results with transgenic mice, ${ }^{[24]}$ we elaborated a nontransgenic mouse model that mimicks the early stages of $A D$ cognitive impairment. A deficit of episodic memory was created in regular mice by a single intracerebroventricular (icv) injection of $A \beta_{1-42}$ oligomers ("icv$A D "$ model). ${ }^{[13 c]}$ No loss of memory was observed when the reverse peptide $A \beta_{42-1}$ was injected, thus indicating the robustness of the model.

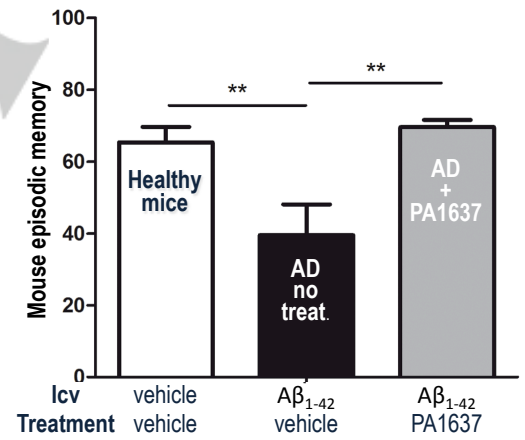

Scheme 5. Episodic memory of non-transgenic AD mice treated with PA1637 at $25 \mathrm{mg} / \mathrm{kg}$ by oral route (grey bar), compared to healthy control mice and untreated $A D$ mice. For details, see Ref. 13c.

Upon an oral treatment of PA1637, a bis(8-amino)quinoline chelator closely similar to AD3 (8 doses of $25 \mathrm{mg} / \mathrm{kg}$ over a 3week period ; for the structure of PA1637, see Scheme 1), the episodic memory of icv-AD mice (Scheme 5, grey bar) was similar to that of healthy animals (white bar), while the episodic memory of $A D$ mice that did not receive treatment was significantly reduced (black bars). Treatment with PA1637 at the lower dose of $12.5 \mathrm{mg} / \mathrm{kg}$ provided the same result. These results indicate that oral administration of PA1637 fully inhibited the cognitive impairment induced by icv injection of $A \beta_{1-42 .}{ }^{[13 c]}$

The in vivo studies with TDMQs are now in progress. Preliminary results indicate that one of these ligands fully inhibited the memory impairment of icv-AD mice upon a 3-week oral treatment ( 8 doses of $10 \mathrm{mg} / \mathrm{kg}$ each). 


\section{Conclusion}

In summary, the design of chelators as drug candidates for copper regulation in $A D$ brain should obey some critical coordination chemistry requirements. Among the various possibilities offered by the diversity of metal ligands, we found that N4-tetradentate 8-aminoquinoline ligands, able to generate stricly square planar $\mathrm{Cu}$ (II) complexes, are the most suitable ligands to transfer copper from metal-amyloids to metal-carrier proteins, and are capable of inhibiting the catalytic reduction of dioxygen produced by copper-loaded amyloids exposed to a reductant. In vivo, such tetradentate ligands are able to inhibit the loss of episodic memory in non-transgenic amyloid-impaired mice. These results strongly support the control of copper homeostasis for $A D$ chemotherapy using copper-amyloid oligomers as drug targets, but not amyloids alone. Pharmacological studies on the most promising TDMQ chelators that exhibit such suitable coordination sphere for copper specificity are currently in progress.

Youzhi Li Youzhi LI received his Master degree in 2019 from the Guangdong University of Technology (GDUT) in Guangzhou, working on the synthesis and physico-chemistry of copper chelators. He is currently PhD student at GDUT.

Michel Nguyen received $\mathrm{PhD}$ degree from the University of Toulouse (2001). He worked for six years in medicinal chemistry for Palumed company, where he developed new antibacterial and antimalarial drugs. He is currently Engineer at CNRS-LCC, working on malaria chemotherapy, and on redox metal homeostasis as possible chemotherapy of Alzheimer's disease.

Morgane Baudoin is currently student at the Chemical Engineering School of Toulouse "ENSIACET".

Laure Vendier Laure Vendier got her engineering degree in Material Physics in 1994 from the National Institute of Applied Sciences (INSA) in Toulouse. She then completed a joint PhD between INSA and Georgia Tech in Atlanta in 1997. She has been a crystallographer engineer at the CNRS since 1998 and has been responsible for the X-ray diffraction facility at the LCC in Toulouse since 2006 .

Yan Liu received her PhD degree from Sun Yat-sen University (2007). After post-doctoral positions at Hong-Kong Baptist University (2007-2009, Prof. Zhi-Hong Jiang), and Kyoto University (2010-2013, Prof. Keiji Maruoka), she joined the research group of Bernard Meunier at the Guangdong University of Technology, Guangzhou. Her current research is focused on the development of specific copper-chelators as potential anti-Alzheimer agents.

Anne Robert received degrees from the Chemical Engineering School of Toulouse, and University of Toulouse (1985, PhD). She joined the research group of Bernard Meunier at the Laboratoire de Chimie de Coordination du CNRS, in 1985. She is currently Director of Research at the CNRS. Her work is focused on the role of redox metals in biology (biomimetic oxidations, mechanism of action of peroxide based antimalarial drugs), and redox metal homeostasis for chemotherapy of Alzheimer's disease.

Bernard Meunier is Emeritus Director of Research at the CNRS (Toulouse), and Distinguished Professor at the University of Technology of Guangdong in Guangzhou (Department of Chemistry) since 2012. He has been an Associate Professor at the "École Polytechnique" (1993-2006) and President of the CNRS (2004-2006). His research covers various fields such as biomimetic oxidations, bioinorganic and medicinal chemistry. Since 2004 , he works on the design of copper chelators as potential drug-candidates for the treatment of Alzheimer's disease. Bernard Meunier is co-author of more than 400 publications and 33 patents. He has been elected Member of the French Academy of Sciences in 1999. He became President of this academy (2015-2016). He is a Foreign Member of the Polish Academy of Sciences (2005) and an Associate Member of the French National Academy of Pharmacy (2013). He received several awards, including the Le Bel Prize of the French Chemical Society in 2007.

\section{Acknowledgments}

This work has been supported by the CNRS since 2003 . Palumed provided a strong support for the period 2005-2010. Since 2013, this work is also supported by the NSFC (grants 21977019 and 21502023), the Guangdong Province (Program for Innovative Research Teams and Leading Talents Introduction, grant 2050205), the Open Project of Guangdong Provincial Key Laboratory of New Drug Screening (No.GDKLNDS-2018OF004) and the University of Technology of the Guangdong (GDUT) (grant 220418037) of the P. R. China.

Keywords: Alzheimer's disease $\cdot$ Copper chelator $•$ Metal homeostasis $\cdot$ Reactive oxygen species

[1] a) World Alzheimer Report 2016, available at https://www.alz.co.uk/research/WorldAlzheimerReport2016.pdf; b) C. A Lane, J. Hardy, J. M. Schott, Eur. J. Neurol. 2018, 25, 59-70.

[2] R. J. Castellani, G. Perry, Arch. Med. Res. 2012, 43, 694-698.

[3] J. L Cummings, T. Morstorf, K. Zhong, Alzheimers Res. Ther. 2014, 6, 37.

[4] J. Cummings, G. Lee, A. Ritter, K. Zhong, Alzheimers Dement. 2018, 4, 195-214.

[5] Lancet 2010, 376, 658-658 (Editorial)

[6] a) K. P. Kepp, Coord. Chem. Rev. 2017, 351, 127-159; b) L. Guilloreau, S. Combalbert, A. Sournia-Saquet, H. Mazarguil, P. Faller, ChemBioChem 2007, 8, 1317-1325; c) Y. Liu, M. Nguyen, A. Robert, B. Meunier, Acc. Chem. Res. 2019, 52, 2026-2035.

[7] The research "Alzheimer AND drug" in Web of Science provides 16774 occurrences, while "Alzheimer AND chelator" provides 357 occurrences, i.e. $2 \%$, and "Alzheimer AND drug AND chelator" provides 102 occurrences, i.e. 0.6\%. Data available on June 28, 2019.

[8] a) W. Zhang, D. Huang, M. Huang, J. Huang, D. Wang, D.; X. Liu, M. Nguyen, L. Vendier, S. Mazères, A. Robert, Y. Liu, B. Meunier, ChemMedChem 2018, 13, 684-704; b) W. Zhang, Y. Liu, C. Hureau, A. Robert, B. Meunier, Chem. Eur. J. 2018, 24, 7825-7829; c) M. Nguyen, A. Robert, A. Sournia-Saquet, L. Vendier, B. Meunier, Chem. Eur. J. 2014, 20, 6771-6785. 
[9] M. A. Lovell, J. D. Robertson, W. J. Teesdale, J. L. Campbell, W. R. Markesbery, J. Neurol. Sci. 1998, 158, 47-52.

[10] a) S. J. C. Lee, E. Nam, H. J. Lee, M. G. Savelieff, M. H. Lim, Chem. Soc. Rev. 2017, 46, 310-323; b) E. Atrián-Blasco, A. Conte-Daban, C Hureau, Dalton Trans. 2017, 46, 12750-12759.

[11] a) A. Robert, Y. Liu, M. Nguyen, B. Meunier, Acc. Chem. Res. 2015, 48 1332-1339; b) K. J. Barnham, A. I. Bush, Chem. Soc. Rev. 2014, 43, 6727-6749; c) L. R. Perez, K. J. Franz, Dalton Trans. 2010, 39, 21772187.

[12] M. Nguyen, L. Vendier, J.-L. Stigliani, B. Meunier, A. Robert, Eur. J. Inorg. Chem. 2017, 600-608.

[13] a) M. Nguyen, L. Rechignat, A. Robert, B. Meunier, Chemistry Open 2015, 4, 27-31; b) M. Nguyen, C. Bijani, N. Martins, B. Meunier, A Robert, Chem. Eur. J. 2015, 21, 17085-17090; c) J. Ceccom, F Cosledan, H. Halley, B. Frances, J. M. Lassalle, B. Meunier, PLoS One 2012, 7, e43105, 1-7.

[14] See Reference 8a for the structures of the $\mathrm{Cu}$ (II) complexes of TDMQ5, 19 and 22, Reference $6 \mathrm{c}$ for the structure of $\mathrm{Cu}(\mathrm{II})-\mathrm{TDMQ} 20$, this article for the structure of $\mathrm{Cu}(\mathrm{II})-\mathrm{TDMQ} 37$.

[15] M. Di Vaira, C. Bazzicalupi, P. Orioli, P. Messori, B. Bruni, P. Zatta, Inorg. Chem. 2004, 43, 3795-3797.

[16] M. S. Shetty, M. Sharma, S. Sajikumar, Aging Cell 2017, 16, 136-148 and references therein.
[17] a) J. L. Arbiser, S.-K. Kraeft, R. van Leeuwen, S. J. Hurwitz, M. Selig, G R. Dickersin, A. Flint, H. R. Byers, L. B. Chen, Mol. Med. 1998, 4, 665 670; b) D. A. Andersson, C. Gentry, S. Moss, S. Bevan, Proc. Natl. Acad. Sci. USA 2009, 109, 8374-8379.

[18] J. Huang, M. Nguyen, Y. Liu, A. Robert, B. Meunier, Eur. J. Inorg Chem. 2019, 1384-1388.

[19] J. D. Bogden, R. A. Troiano, M. M. Joselow, Clin. Chem. 1977, 23, 485489.

[20] a) J. P. Phillips, Chem. Rev. 1956, 56, 271-297; b) I. M. Nagpure, M. M. Duvenhage, S. S. Pitale, O. M. Ntwaeaborwa, J. J. Terblans, H. C Swart, J. Fluoresc. 2012, 22, 1271-1279.

[21] P. A. Adlard, R. A. Cherny, D. I. Finkelstein, E. Gautier, E. Robb, M. Cortes, I. Volitakis, X. Liu, J. P. Smith, K. Perez, K. Laughton, Q.-X. Li, S. A. Charman, J. A. Nicolazzo, S. Wilkins, K. Deleva, T. Lynch, G. Kok, C. W. Richtie, R. E. Tanzi, R. Cappai, C. L. Masters, K. J. Barnham, A. I. Bush, Neuron 2008, 59, 43-55.

[22] H. Pajouhesh, G. R. Lenz, NeuroRx 2005, 2, 541-553.

[23] $\log P$ and tPSA values were calculated using ChemDraw Prime software, v. 16.0.1.4.

[24] C. Boldron, I. Van der Auwera, C. Deraeve, H. Gornitzka, S. Wera, M Pitié, F. Van Leuven, B. Meunier, ChemBioChem 2005, 6, 1976-1980. 
Entry for the Table of Contents (Please choose one layout)

Layout 1:

MINIREVIEW

Text for Table of Contents

To efficiently regulate copper homeostasis in the brain of patients with Alzheimer's disease, the designed chelators should obey to some critical coordination requirements. N4-tetradentate 8aminoquinoline ligands, that generate square planar $1 / 1 \mathrm{Cu}$ (II) complexes, efficiently inhibit the $\mathrm{Cu}$-amyloid induced oxidative stress wich is an important pathological hallmark of Alzheimer's disease.

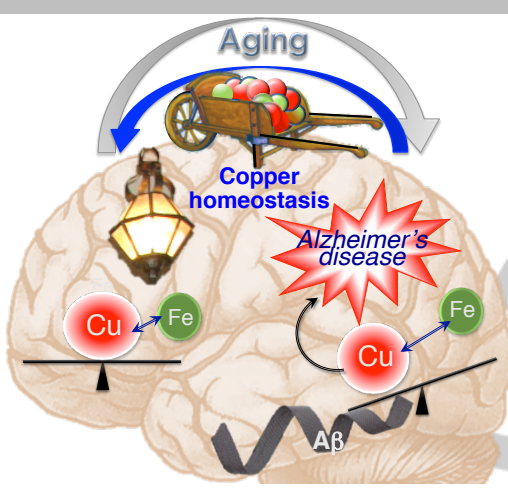

Drugs for Alzheimer's disease*

Author(s), Corresponding Author(s)* Youzhi Li, Michel Nguyen, Morgane Baudoin, Laure Vendier, Yan Liu*, Anne Robert*, Bernard Meunier*

\section{Page No. - Page No.}

Why tetradentate coordination is essential for potential copper homeostasis regulators in Alzheimer's disease?

Layout 2:

MINIREVIEW

((Insert TOC Graphic here; max. width: $11.5 \mathrm{~cm}$; max. height: $2.5 \mathrm{~cm}$ : the final letter height should not be less than $2 \mathrm{~mm}$.))

\section{Key Topic*}

Author(s), Corresponding Author(s)*

Page No. - Page No.

Title

Text for Table of Contents (about 350 characters)

*one or two words that highlight the emphasis of the paper or the field of the study 